\title{
A Bird in the Hand: Hunting, Fashion and Colonial Culture
}

KATE HUNTER

Birds and feathers were everywhere in the colonial world: in the street, at exhibitions (probably as much on show by the audiences as in the glass cases); in opera houses, at weddings and society events. They abounded at the opening of the Auckland Free Library in April 1887. ${ }^{1}$ Through newspaper advertisements we know they turned up in auction houses among house lots ${ }^{2}$ and were advertised as lost and found. ${ }^{3}$ They were a feature of ceremonies and military parades for both men and women. Feathers and bird skins were hunted and salted, bought and sold, dressed and dyed, mounted and stitched. In milliners' shops they were caressed, perused, tried on by ladies or perhaps bought by a gentleman, presented to a wife, lover or sister, then unwrapped, bringing delight. They were worn, admired and reported upon. But these final performances of taste and class were a far cry from the forests of south Westland, billabongs of New South Wales, jungles of Papua New Guinea and South America, or the veldt of South Africa.

Training our analysis on or through objects, especially those made from animal skins, can illuminate more clearly the layers of the Pakeha colonial world. Archaeologists and ethnographers have long studied the wearing of feathers and skins in indigenous cultures, but less attention has been paid to the meanings of this practice, nor the intertwining of it with indigenous traditions, in white settler cultures. ${ }^{4}$ White settler societies such as New Zealand abound with trophies and skins but other animal objects are much less celebrated or even noticed. They are more domestic yet equally tied to hunting and empire: ivory piano keys, bone-handled knives and feather garments or hats. ${ }^{5}$ The importance of clothing to gender, age, and religious and class identities was exacerbated in colonial society, where the 'usual' mechanisms of establishing reputation - those of introduction, association with the correct families and references quickly sought and gained by return post - were unavailable or only newly developed. ${ }^{6}$ Hence, an exploration of sartorial practices and their connection to various practices of work can reorient understandings of colonial culture that have tended to be horizontal - examining a particular class or group - and fill in some of the vertical framework.

This essay focuses broadly on birds and their feathers as a commodity as a way of illuminating how different contexts could shape meaning in 
antipodean colonial societies. It explores the work of hunting, processing and trading of feathers and birds, demonstrating the overlap and interplay of the natural history specimen market and the garment manufacturing industry. The essay then discusses the workers who integrated feathers into fashionable garments, and the meanings attached to wearing those garments. A trade such as feathers also illuminates the extent to which New Zealand was integrated into an international trade network that led to similar work cultures and dress cultures developing in other colonial centres. As such, a range of colonial examples appears in this essay in order to shed light on the wider settler world of which New Zealand was a part.

Several scholars have suggested that a 'biographical approach' to things can illuminate both the movement of objects through and between cultures, and the way their meaning changes with context.? Frank Trentmann has warned, however, that this approach - the development of material culture studies based broadly on museum studies - has resulted in a proliferation of histories of 'taste and aesthetics, studies of shopping, and discussion of possessions and heirlooms in the construction of social, gender, and family identities'. He also argues that at the same time there has been 'remarkably little reverse flow of new approaches of materiality from neighbouring disciplines into history', and indeed the gulf has widened between 'material culture, focussed on identities and representations, and material politics and political economy'. ${ }^{8}$ In a recent survey of the state of material histories in Australia and New Zealand, Bronwyn Labrum was slightly less pessimistic, suggesting that the gulf has perhaps been bridged a little more in recent years, but she agrees with Trentmann that much work on material culture 'remains within an overall framework of consumption, focussed on purchase, acquisition and shopping, rather than material use'.

Material use is important in understanding the meanings of clothing. Costume historian Jane Malthus has argued in her study of clothing production and consumption in Caversham (Dunedin) that the material and symbolic structure of clothes and textiles reflects both private or individual concerns and interests, and larger social issues of class, religion and culture'. ${ }^{10}$ As highlighted by the work of Jill Fields on the history of lingerie, particularly black lingerie, the manufacture of clothing could also reflect some of these interests and divisions. She highlights the different meanings constructed around materials by different sets of hands. In the hands of African-American undergarment workers in the 1950s, black lingerie was not, she argues, a sign of eroticism, as it was for the women purchasing and wearing black lingerie, but of discrimination. When these workers returned from holidays or sick leave they would find stacks of black undergarments next to their machines 'left for them by their largely immigrant co-workers because sewing black thread on black fabric was 
more difficult'. ${ }^{11}$ The meanings of feathers and furs, as we shall see, also had different meanings for those who worked with the materials rather than wore them.

A muff in the collection of the Museum of New Zealand Te Papa Tongarewa usefully provides an entry into the world of feather garments in New Zealand. ${ }^{12}$ It is made from a whole skin of a spotted kiwi. The skin was padded and lined with chocolate brown silk before being rolled and secured. A casing at each end holds a cord that cinches in the ends of the tube, and attached to one end are two brown tassels. It came into the national museum collection in 1949 as part of the bequest made by Marjorie Hector, the daughter of Colonial Museum director James Hector. In Hector's papers is a letter showing that in 1872 he sent five kiwi skins to Thomas Kirk, director of the Auckland Museum, to be taken to a Ponsonby furrier. There they were made into 'a tippet and muff' ${ }^{13}$ There is reason to suggest that this very muff is now in Te Papa.

Before it was a muff, of course, it was a bird. Kiwi first became known to European naturalists in 1812 via a skin traded through Captain Barclay (Barclay never visited New Zealand but transported convicts. He probably picked the skin up in Sydney). Barclay sold it to George Shaw, keeper of zoology at the British Museum, who named it apteryx australis. Kiwi remained an enigmatic species as far as Europeans were concerned; while their feathers often arrived in London in Maori cloaks, larger numbers of whole specimens and skeletons did not arrive in Europe until the 1830s and 1840s. It was not until 1850 that enough information had been collected on North Island species to distinguish Shaw's initial specimen as from a South Island species. ${ }^{14}$

A bird hunter, probably working for a natural scientist or hoping to sell to one on spec, shot the kiwi that became Marjorie Hector's muff. Whether he was Maori or Pakeha is not known. Maori bird hunters appear occasionally in the historical record: Walter Buller particularly recorded travelling with Maori kiwi and huia hunters. ${ }^{15}$ Runholder and naturalist John Enys wrote in 1875 that more than 600 huia skins had been collected from Maori in the northern Wairarapa in one year. ${ }^{16}$ A little more information exists about Pakeha bird hunters in New Zealand: they were bushmen, lighthouse keepers and sometimes farmers looking to earn a little cash. Julius von Haast paid out a great deal of money over several decades to skin collectors. Prices were based on rarity and international demand. For one consignment from William Docherty at Okarito, which totalled $£ 40$ worth of skins, skeletons and eggs, Haast paid for: ' 9 Ka-Ka Pos $£ 9,2$ dozen Kiwi skins £7.4.0 . . . 6 Rowi [Okarito Brown kiwi] skins $£ 6$. . 26 birdskins at 4/- each £7.4.0,. ${ }^{17}$ In July 1873 Haast offered West Coast hunter Leo Barnes 10 shillings each for kotuku ('white crane'). W.J. Wheeler supplied Haast at the agreed price 
of 20 shillings for 'roa' skins [great spotted kiwi], eight shillings each for kakapo and smaller kiwi; five shillings for kaka and kereru, and all sea birds at $£ 210$ s per dozen. ${ }^{18}$ While these skins were ostensibly collected for natural history purposes, it is clear in the case of birds collected in other countries that by the 1840 s surplus natural history skins were being sold on to milliners. William Docherty told naturalist Thomas Potts that he had sold 2000 kiwi skins to a London agent to be sold on to the garment industry. ${ }^{19}$ The arsenic-preserved skins of natural history collectors were vastly preferred to the bark-preserved skins prepared by indigenous people. Naturalist Alfred Russel Wallace recorded that, consequently, the price of locally prepared Bird of Paradise skins in New Guinea plunged from up to $£ 2$ each for some species to only sixpence over the course of the $1840 \mathrm{~s}^{20}$

The challenge for bird hunters was not simply finding the birds, but finding them at the right time. Birds have seasonal moults and develop breeding plumage, so some basic knowledge of habitat and bird physiology was necessary. Hunters also had the challenge of keeping skins and plumes from getting dirty, bloody, muddy, wet or mouldy. David Bennett, a Californian egret hunter who hunted in Mexico and Central America, complained that feather traders examined scrupulously with a magnifying glass plumes brought in for sale. The slightest mark or stain on the feather, especially, of course, on white ones, reduced their value by up to $50 \% .^{21}$ No one became rich through plume- or skin-hunting, but it was, in New Zealand, one of the various income-supplementing strategies that could be combined with other bush work.

It is generally assumed that the ecological culture of an area could be altered by hunting, but we must be cautious in assessing the effects. The impact of hunting on bird populations is extremely difficult to gauge: different species were subject to different pressures in different environments. In New Zealand, large-scale habitat modification, especially the burning of bush for pasture, had the greatest impact on ecology. New Zealand's birds were also affected by other, much less visible factors, including the introduction of predators and changes in water quality. Even small changes affected species such as the whio/blue duck, whose retreat from lowland waterways began almost immediately once livestock were introduced. ${ }^{22}$ South Island explorer Charlie Douglas saw the immediate effect of Pakeha settlement on birds as being the introduction of domestic cats and dogs. ${ }^{23}$ Overall, it is very difficult to untangle the effect on birds of the destruction of forests for agriculture, introduction of predators, hunting for food and skins, and competition from livestock. And not all birdlife was threatened by colonization: Australian historian Bill Gammage, for example, has recently demonstrated that galahs were beneficiaries of the introduction of cattle to Australia. As groundfeeding seed eaters, galahs' food sources were increased by cattle which 
trampled and ate tall native grasses down to a level where galahs could reach the seed heads. Through European expansion, they have extended their range to become almost ubiquitous. ${ }^{24}$ Similarly, in New Zealand the native hawk or kahu was advantaged by the clearing of forested lands for pasture, thus creating the open grasslands suitable for hunting. Indeed, kahu became so successful that acclimatization societies posted a bounty on them when they became seen as a threat to lambs. ${ }^{25}$

The numbers of birds killed by hunters is astronomical, however. Records of auction houses in London and New York show that each year they cleared millions of natural history specimens, feathers, wings and whole birds, from around the world. A London dealer warned Walter Buller in 1880 that he would accept no more New Zealand birds because he still had 385 kakapo and 90 little spotted kiwi in stock. ${ }^{26}$ The American ornithological magazine The Auk noted in 1888 that 'Last year, the trade in birds for women's hats was so enormous that a single London dealer admitted that he had sold 2,000,000 of small birds of every kind and colour'. ${ }^{27}$ In records of London auctions in 1908, lists still included 180 Australian native lyre bird tails. ${ }^{28}$

Feathers and bird skins in New Zealand were a mixture of those of native birds and imported millinery supplies. In newspaper reports on the costumes of brides and women at events, ostrich plumes are common, as are egret (usually referred to as aigrette or osprey) feathers. Photographic evidence suggests that many other species were available also. London auction houses were the end of a long chain of suppliers that stretched through sub-Saharan Africa, North Africa, the Mediterranean and the Americas. ${ }^{29}$ Feathers could also come from slightly closer to home. In a report to the House of Representatives considering a settlement on Stewart Island in 1872, feather collecting was listed among 'miscellaneous occupations': mutton bird feathers were selling at five pence per pound; 'Albatross for considerably more'. ${ }^{30}$ White birds or white-breasted birds were always in demand and fetched higher prices from the feather traders. This perhaps explains the preponderance of water and sea birds in the lists of birds procured for millinery. ${ }^{31}$

From auction houses in New York and London, feathers were dyed largely in Germany, the centre of Europe's dye industry. Oxidization dyes, whereby an even colour could be produced, were developed in Germany in the 1880s. ${ }^{32}$ Indeed, Germany was still considered the centre of the dying industry on the outbreak of World War One. In 1915 Mary Buckland wrote to the Australian and New Zealand newspaper in London, the British Australasian:

Sir - it is often said that if women knew of the horrors which characterize the feather trade they would refrain from wearing these trappings of the savage. Be that as it may, surely when it is made known to the 
mothers, wives and daughters who are today mourning their dead, that this cruel trade is largely in the hands of the nation which has made this war, there will be an instant outburst of indignation against this form of millinery ...

Would it be out of place to ask every woman in the country with any sense of the fitness of things to enter upon the New Year with a stern and inflexible resolve to abstain from wearing anything but the most discreet of hats? $?^{33}$

In New Zealand, while some feathers did arrive in the country pre-dyed, feathers and skins were also dyed and made up into garments and trims by specialist furriers, milliners and modistes or costumières (specialist dressmakers). Mrs Janet Yardle had made up James Hector's kiwi skin into a muff in Ponsonby; J.A. Capper advertised as a 'Taxidermist, Furrier and Plumassier' in Wanganui; ${ }^{34}$ John Jacobs advertised as a 'Feather Furrier and Taxidermist . . . every description of sea and land birds prepared and made into muffs \&c'. ${ }^{35}$ Mrs Alice Jacobs offered 'feathers cleaned, curled and dyed' as part of her services as a taxidermist and furrier. ${ }^{36}$ Perhaps the best known of these 'feather furriers' was Hector Liardet of Wellington. In his advertisements in 1875 Liardet urged his patrons to consider as presents for friends in England 'muffs, tippets, cuffs, ladies' head-dresses $\& c$ made from the choicest sea and land birds of New Zealand'. He assured customers he could fill orders quickly because he had 'upwards of 1,000 prepared skins on hand'. ${ }^{37}$ Liardet exhibited at the Philadelphia Exhibition in 1876 through to the Paris Exhibition of 1890. The description of the New Zealand court at Philadelphia reveals the range of 'natural riches' on display in their various forms:

Continuing to the back of the section . . . are three handsome upright cases of walnut wood . . . In the first, on either side of the main entrance, are placed a selection of beautiful articles of ladies' dress, manufactured from feathers of sea birds by Liardet of Wellington. Over these on one side, are suspended plates from Dr Buller's great work on the ornithology of New Zealand; and on the other, groups of photographs of Maoris, all mounted in inlaid frames, which show to great advantage. ${ }^{38}$

At the Paris Exhibition in 1890, Liardet again won medals for his collarets and muffs from the skins of New Zealand birds. His muff from the skin of a Royal Penguin (from Macquarie Island) attracted 'an immense amount of attention' and his hat made of the plumage of a speckled shag was bought by the Baroness Rothschild. ${ }^{39}$

Liardet's business demonstrated the interweaving of natural history and women's garments on the one hand, and the crossover between 'feather furriers' and dressmakers on the other. In advertisements Liardet's firm 
also offered 'Dressmaking in the most elegant and fashionable style'. ${ }^{40}$ That natural history preservation, the manufacture of feathers into women's garments, and dressmaking were going on under the same roof indicates the overlap of skilled workers and equipment needed for each enterprise. There were connections of materials, skill and sometimes of space between the cultures of taxidermy and those of women's fashion.

Manufacture of women's clothing had its own culture within the skilled trades. Dressmakers in New Zealand were very often also milliners: Jane Malthus has shown that it was almost the end of the nineteenth century before the population was large enough for 'these occupations to become separate specialties'. ${ }^{41}$ Both dressmakers and milliners were distinguished from seamstresses by skill and experience. Seamstresses stitched pieces together but did not cut. Modistes or costumières fashioned gowns to suit individual patrons. This was an important skill in 'an era when the fit of a dress - even more than the richness of its fabrics or the extravagance of its trimmings - distinguished the elite from "the puckered, gaping, baggy masses", ${ }^{42}$ Similarly, milliners were distinguished from dressmakers by the range of raw materials with which they had to work, and the sheer variety of hat and bonnet shapes, as well as trimmings. As American historian Wendy Gamber elegantly puts it, 'they were designers as well as craftswomen, artists as well as artisans'. ${ }^{43}$ Milliners and dressmakers typically earned twice as much as seamstresses, such was the distinction in and recognition of skill. ${ }^{44}$

Advertisements in New Zealand newspapers reinforce this connection between millinery and dressmaking, as well as the caché of training in the centres of European fashion. In 1850, Miss Brickwell (of London), milliner, dress and stay maker, advertised for an apprentice; Mrs Green wanted only a 'first rate' milliner and dressmaker to join her workroom in 1858; Miss Marriot had premises on Lambton Quay in 1870; in 1881 'Madame de Meden from London' announced that she had commenced business 'upon most reasonable terms, as a fashionable milliner and dressmaker'. ${ }^{45}$ Mrs Bailey worked in Nelson, Miss Austin in Reefton, and in the 1860s Queenstown had at least three dressmakers servicing the female population. ${ }^{46}$ These simple announcements and advertisements conceal a work culture that revolved around not just a girl's ability with the needle, but her cleanliness. Milliners' hands and work clothes had to be clean to be able to work with the whitest fabrics and feathers. This created hierarchies in workrooms, with only some girls, those from 'clean' homes, being allowed to work with 'the whites'. ${ }^{47}$

Drapers' shops, too, employed in-house milliners and dressmakers. When the larger shops expanded into the 1880s to department stores, dressmaking and millinery became departments supervized, in the case of the Drapery and General Importing Company (DIC), by a 'lady trained in London, 
Cheltenham and Edinburgh'; and in 1899 draper James Beattie announced to the ladies of Gore that his new milliner, Miss Sutherland, had arrived 'with all the newest fashions from Dunedin'. ${ }^{48}$ Indeed, Dunedin - arguably the most fashionable city of nineteenth-century New Zealand - was alive with dressmakers and milliners. Stone's Otago \& Southland Directory listed 52 dressmakers and milliners in Dunedin city alone in 1887, peaking in 1910 with over 70 dressmakers listed, a number that, despite the increasing availability of off-the-rack clothing, did not diminish until $1930 .{ }^{49}$ Milliners too remained very important, because factory-made women's hats were difficult to get: Sargood, Son \& Ewan were the first to open a hat factory in 1901. Indeed, from the example of clothing manufacturers Ross \& Glendining's attempts to establish a hat factory in Dunedin it is clear that the particular demands of hat shaping and trimming were not well suited to the factory setting. As a result, small millinery workshops and pieceworkers working from home remained the norm well into the mid-twentieth century.

Ross \& Glendining began production of women's clothing in 1907, when fashions had changed sufficiently to make large-scale production of clothing possible, and when tariffs were reduced on crepes, silks and laces. ${ }^{50}$ Nonetheless, they relied on New Zealand women's willingness to choose clothes that were sufficiently stylish to warrant the expense. After the Tailoresses' Union informed Ross \& Glendining that all union members in New Zealand were employed, Ross \& Glendining advertised in the Melbourne newspapers for women to work in their factories: passage was advanced and then recovered from wages. ${ }^{51}$ They also used this method of recruitment for their hat factory (at least until 1911, when legislation prevented employers from recovering the cost of passage from wages). They were able to obtain experienced workers for their straw hat making without much difficulty. The Brown family, for example, which comprised a married couple, 'their son-in-law, two machinists, a finisher and apprentice', were engaged after they approached Ross \& Glendining as the factory was being completed in 1902.52 Despite the small fortune required to establish the factory - plant and machinery alone costing $£ 5500$ - the straw hat side of the enterprise was making a small profit by 1905 . The felt hat making side of the business was, by contrast, a disaster. The machinery was very expensive and the process required a great deal of expertise, expertise that was not available in New Zealand in great quantity. Workers were recruited from England and Australia, but many proved unsatisfactory. As evident from Ross \& Glendining's experience, hat making was a combination of technical expertise and artistry that was difficult to replicate in the factory setting and New Zealand did not have a workshop culture of milliners and hatters from which to draw. 
Their particular skills led milliners and dressmakers to occupy a particular niche in the colonial world: they were essential to colonial culture and yet caused significant anxiety. 'Dressing well was a requirement of the job' not only for dressmakers but for prostitutes also, making dressmakers vulnerable to social confusion. ${ }^{53}$ Melbourne coroner Curtis Candler related in his diary a scene he witnessed on Collins Street in which a young woman who had "attracted the attentions of a man who took her for a prostitute suddenly "swept past him, got into a well appointed carriage that had just driven up [an unmistakable sign of respectability], and went off laughing at his discomfiture" ${ }^{54}$ In New Zealand court cases involving women who were dressmakers they almost invariably had to defend themselves against charges of brothel-keeping. For example, Hannah Fallon was the victim of a burglary in 1879 but knew one of the accused, who claimed her house was 'a kind of a brothel'. She asserted: 'I do not carry on any business but that of dressmaking. I do not know that my house is a known brothel. It is a decent respectable house'. ${ }^{55}$ The fact that some women did include both prostitution and dressmaking in their income-earning strategies added to the confusion. For example, Ethel Bushby, who had been 'living in a house of ill fame in Abel Smith Street' when she was visited by Samuel Berg (now being divorced by his wife), was by the time of the Berg's divorce case a dressmaker. ${ }^{56}$ In an assault case against Ellen Mahoney in 1872, various witnesses who were called identified their occupations variously as dressmakers or, as the judge characterized them, "in the "fancy-man" line'. ${ }^{57}$

Dressmakers' skills in facilitating stylish respectability could not, however, create an equal power relationship with their customers. On the one hand their important skills meant they had some economic power, over pricing; on the other their women customers could be at the mercy of a husband who would not settle accounts because of their wife's extravagance. In Manawatu, Sarah Liggins, who was a sewer herself but too busy to sew her own clothes, complained bitterly in letters to her mother and sister-inlaw about the dressmakers' charges for even the plainest of day dresses. ${ }^{58}$ Meanwhile, dressmakers and furriers were likely to have been among the many victims of defaulters, especially when announcements appeared in colonial newspapers declaring husbands exempt from honouring wives' debts (usually when the wife had left home). John McGregor placed such an announcement in the Wellington Independent in August 1863 after his wife 'left home of her own free will'. ${ }^{59}$ Similar announcements continued to appear in the later nineteenth century, and by 1925 such announcements were so common that the Evening Post ran a full legal explanation of husbands' obligations and rights under these circumstances. ${ }^{60}$ The pursuit of small debts through the courts also indicates that defaulting on debts of less than 
$£ 20$ was rife in colonial society. In 1886 alone, 20,380 cases for recovery of small debts were pursued through the court system. ${ }^{61}$ Furriers, such as Hector Liardet, also appeared along with other merchants as unsecured creditors in bankruptcy notices. ${ }^{62}$

The appearance in the nineteenth century of muffs as a fashionable item was connected to changes in dress design. The demise of the crinoline corresponded with increasing focus on the upper parts of the body - the puff of sleeves, a 'wealth of hair', head dresses and hats rather than bonnets. ${ }^{63}$ With the increasingly slimmer silhouettes of dresses, "hats were made to look higher by the addition of feathers and luxuriant flower arrangements. They were mostly tilted forwards', necessitating and leading to the popularization of hatpins.$^{64}$ Fashion historian Margarette Braun-Ronsdorf describes how as dresses became straighter with more relaxed silhouettes, 'only the hats kept their enormous size for a while, as if there had to be something voluminous somewhere. Huge muffs of fur or fabric, or large handbags helped to balance them. ${ }^{65}$

Braun-Ronsdorf also notes that 'Apart from . . . the masses of artificial flowers, hat decorations consisted almost exclusively of ostrich plumes' ${ }^{66}$ Indeed, feathers on women's hats are absolutely everywhere in New Zealand newspapers and photographs from the 1870s onwards. The Princess of Wales was reported as looking very elegant in 1873 in a dark violet merino costume, velvet bonnet 'of the same shade with a sea blue feather'. ${ }^{67} \mathrm{~A}$ decade later the author of 'Notes for the Ladies' in the Canterbury Star remarked that bonnets of the season were 'of every shape, shade and design - in coloured straws, some trimmed with a profusion of flowers, feather aigrettes or bows' ${ }^{68}$ Even the most cursory glance through reports of weddings reveals, by the turn of the century, bridesmaids, mothers of the bride and groom, cousins and sisters of a range of social classes adorned with plumes. Maggie Quick wore a white ostrich feather boa when she married stationmaster Frank Delany in Paeroa in 1906; Florrie Ward wore a cream leghorn hat trimmed with feathers and a lace and white gossamer veiling when she married dentist Robert Young in 1899. Alice Harrison when she married in 1902 was attended by bridesmaids in the extremely fashionable 'magpie' gown; that is, a combination of whites and blacks in feathers and fabrics. Her cousin, Miss Bell, was more striking perhaps in a 'canary' dress with a hat to match trimmed with yellow roses and bird of paradise feathers. ${ }^{69}$ Perhaps overdoing it a little was Ann Wyatt Blatt, who in 1899 married estate manager James Georgetti wearing a maize-coloured gown with swansdown and white lace trimmings together with the customary veil with orange blossom; her travelling outfit was made of 'grey tweed (tailor made), with felt hat and huia feather' ${ }^{70}$ 
Feathers were also absent. There were no feathers mentioned at all in reports of the wedding of New Zealand premier Richard Seddon's daughter Jane to Reverend W.S. Bean in 1891; the symbols of piety and purity, orange blossom and tulle, prevailed. ${ }^{71}$ Other brides of Anglican curates were almost identically attired even if they were of a higher class than the Seddons, as in the case of Marion Henty (third generation of Victoria's founding family) who married Reverend Thomas Armstrong in Melbourne in $1893 .{ }^{72}$ When Phoebe Seddon married Frank Dyer in 1897, however, the slightly more mature Jane Bean (née Seddon) was reported as looking 'pretty in ... black ostrich feathered hat with mauve and green shot ribbon'. Among the guests only one other feathered hat was reported, however. ${ }^{73}$ Feathers clearly were not popular among the Anglican, respectable, middling classes. Instead, Phoebe Seddon's bridesmaids wore picture hats that were towers of pure froth. ${ }^{74}$

As historian Penny Russell's careful portrait of the 'genteel performance' in colonial Melbourne has demonstrated, the ongoing definition of gentility and maintenance of social power was in part dependent on women's use of dress and space..$^{75}$ In a world where colonial governors' wives, highly-skilled costumiers, opera singers and prostitutes wore or carried feathers, inflection was all.

Just as London and Paris fashions had appeared in New Zealand, so too did appeals for women to eschew 'cruelty in fashion'. Campaigns were launched from the mid-1880s by ornithologists and naturalists in an attempt reduce demand for feathers. Stories appeared in newspapers telling of slaughter of adult birds in egret colonies, leaving hundreds of chicks to starve or fall from their nests and drown. The blame for the rarity of many species was laid squarely at the feet of women's vanity, not at the boots of regiments of men in dress uniform. In 1902 the Colonist reported that 'The King and Queen strongly deprecate the killing of birds for hat trimmings when informed that a certain milliner had contracted for 10,000 seagulls' wings for London and Paris orders. ${ }^{76}$

Thomas Kirk had quipped in his 1872 letter accompanying the kiwi muff back to James Hector that 'poor kiwi' needed protection against 'the vanity of titled ladies'. ${ }^{77}$ This was a joke, and the cry of 'cruel fashion' never really caught on in New Zealand. Bird protection had revolved around a different question altogether - that of hunting for food. Where American governments were legislating to protect their native birds against feather hunters, the New Zealand government was pressured by naturalists and sport hunters to protect native birds against pot-hunting by both Maori and Pakeha bush workers. Maori MPs, on the other hand, pointed out that perhaps agriculture was to blame. From 1907 legislation to protect New Zealand's native birds became progressively stronger, instituting seasons, banning the sale of birds 
to restaurants and outlawing some hunting methods. It was not until 1922 that native birds received complete protection from hunting. ${ }^{78}$

As historians of materiality remind us, objects speak. They are products of cultures, although often their full meaning is hard to grasp. Historians of the nineteenth century have a range of supplementary sources to draw on in the pursuit of understanding the place of objects and garments in colonial cultures. It is important to focus, however, on the full range of materials and their various journeys through ecological, workplace and sartorial cultures. Focusing on the consumption of objects can tell us only part of the story: consumption usually only illuminates those who could afford to buy and the events at which they displayed their new hats. Similarly, to focus on hunting as a trophy-procuring exercise, as some historians have done, neglects a whole range of hunters. In exploring the hunting, harvest and acquisition of materials as well as the various skilled artisans who created the garments, objects such as Marjorie Hector's muff can link the inarticulate actors in the colonial past with cosmopolitan cultures of merchants and opera singers.

1 'Ladies Dresses at the Opening of the Free Library', Observer (Auckland), 2 April 1887, p.4.

2 Advertisement, Star (Dunedin), 14 March 1878, p.2.

3 'Found on Sunday last - an Albatross muff. Owner can have it on paying for this advertisement. CM Wilson, Devonport Rd ... Lost 10s reward. Lost near Mrs Fielding's on the Strand. A white feather muff . . , , Bay of Plenty Times, 31 July 1883, p.3.

4 See, for example, Stuart A. Marks, Large Mammals and a Brave People, Seattle, 1976, on the Bemba people of Zambia. Mahesh Rangarajan, India's Wildlife History: An Introduction, Delhi, 2005 contrasts princely practices with later colonial hunts. Sylvia van Kirk, Many Tender Ties: Women in Fur Trade Society, 1670-1870, Norman, OK, 1983 , focuses on the intertwining of indigenous and non-indigenous communities in the pursuit of furs.

5 John MacKenzie, Empire of Nature: Hunting, Conservation and British Imperialism, Manchester, 1988, explores the trade in ivory and antlers for household items, but he does not write about clothing.

6 On the importance of clothing see Laura Ugolini, Men and Menswear: Sartorial Consumption in Britain, 1880-1939, Aldershot, 2007; on the unavailability of the usual mechanisms of checking reputation see Penny Russell, A Wish of Distinction: Colonial Gentility and Femininity, Melbourne, 1994.

7 For example, Arjun Appadurai, ed., The Social Life of Things: Commodities in Cultural Perspective, 2nd edn, Cambridge, 1992; and Ugolini.

8 Frank Trentmann, 'Materiality in the Future of History', Journal of British Studies, 48 (April 2009), pp.284-5.

9 Bronwyn Labrum, 'Material Histories in Australia and New Zealand', History Compass, 8,8 (2010), p.812.

10 Jane Malthus, Caversham Working Paper CWP2000-7, unpublished working paper, MS2690/228, Hocken Collections, Dunedin, p.2. 


\section{Hunting, Fashion and Colonial Culture}

11 Jill Fields, 'From Black Venus to Blonde Venus: The Meaning of Black Lingerie', Women's History Review, 15, 4 (September 2006), p.611.

12 PC000107 Kiwi skin muff, Marjorie Hector Collection, Museum of New Zealand Te Papa Tongarewa, Wellington.

13 Paul Star, 'From Acclimatisation to Preservation: Colonists and the Natural World in Southern New Zealand, 1860-1894', PhD thesis, University of Otago, 1997, p.137.

14 Darren Naish, '200 Years of Kiwi Research', http://scienceblogs.com /tetrapodzoology/2009/02/200_years_of_kiwi_research.php.

15 Ross Galbreath, Walter Buller: The Reluctant Conservationist, Wellington, 1989, pp.143-5.

16 J.D. Enys, 'An Account of the Maori Manner of Preserving the Skin of the Huia Heteralocha auctirostris, Buller', Transactions and Proceedings of the Royal Society of New Zealand, 8 (1875), p.205.

17 Docherty, cit. Sally Burrage, 'Exchange of Native Bird Skins, Skeletons and Eeggs by Canterbury Museum from 1869-1913', Records of the Canterbury Museum, 15 (December 2001), p.1.

18 Leo Barnes, letters from Julius von Haast, 216/86, folder 797, Canterbury Museum, Christchurch; H.F. von Haast, The Life and Times of Sir Julius von Haast: Explorer, Geologist, Museum Builder, Wellington, 1948, p.557.

19 Thomas Potts in Star, pp.142-3.

20 Pamela Swadling, Plumes from Paradise: Trade Cycles in Outer Southeast Asia and their Impact on New Guinea and Nearby Islands until 1920, Boroko, PNG, 1996, p.83.

21 Bennett's story is reproduced in Robin W. Doughty, Feather Fashions and Bird Preservation, Berkeley, 1975, pp.72-4.

22 David Young, Whio: Saving New Zealand's Blue Duck, Nelson, 2006.

23 Charlie Douglas, cit. David Young, Our Islands, Our Selves: A History of Conservation in New Zealand, Dunedin, 2004, p.80.

24 Bill Gammage, 'Galahs', Australian Historical Studies, 40, 3 (2009), pp.275-93.

25 See http://www.nzbirds.com and Kate Hunter, Hunting: A New Zealand History, Auckland, 2009, pp.142ff about bounties.

26 Galbreath, p.143.

27 Auk, 1888, p.335 in Doughty, p.30.

28 Doughty, p.30.

29 See for example Sarah Abrevaya Stein, “Falling into Feathers": Jews and the TransAtlantic Ostrich Feather Trade', Journal of Modern History, 79 (December 2007), pp.772-812.

30 Papers Relating to Special Settlement on Stewart's Island, Appendices of the Journal of the House of Representatives (AJHR), 1872, Session I, D-07a, p.10.

31 See, for example, 'Report of Committee on Bird Protection', Auk, vol.xviii, January 1901, pp.74-5. The demand for white feathers also occurred because it was not until the 1920s that bleaching to a true white was perfected for furs and feathers. See Harry Kaplan, Furskin Processing, Oxford, 1971, p.165.

32 Evan Tosh, 'From Furs to Furriers in Dunedin, New Zealand to 1940', Masters of Consumer and Applied Science thesis, University of Otago, 2005, p.19.

33 British Australasian, 7 January 1915, p.5. 


\section{Journal of New Zealand Studies}

34 Wanganui Herald, 6 April 1876, p.2.

35 Nelson Evening Mail (NEM), 4 July 1884, p.4.

36 Evening Post (EP), 14 October 1897, p.1; there is also an A.J. Jacobs listed as a taxidermist in Dunedin in the 1914 volume of Stone's Otago \& Southland Directory.

37 EP, 8 March 1875, p.3. John Jacobs of Nelson also advertised that he had 'bird skins $\& c$ for export always on hand', NEM, 27 February 1888, p.2.

38 James Hector, 'Description of the New Zealand Court in Philadelphia Exhibition, 1876', AJHR, 1877, Session 1, H-23, p.28.

39 EP, 5 January 1890, p.3.

40 EP, 11 April 1874, p.4.

41 Jane Malthus, 'Dressmakers in 19th Century New Zealand', in Barbara Brookes, Charlotte Macdonald and Margaret Tennant, eds, Women in History 2, Wellington, 1992, p.78.

42 Wendy Gamber, The Female Economy: The Millinery and Dressmaking Trades, 18601930, Urbana \& Chicago, 1997, citing Amy Simpson, p.12.

43 Gamber, p.12.

44 In New Zealand milliners earned slightly more than dressmakers, but both earned far less than tailors. See Malthus, 'Dressmakers', p.79.

45 New Zealander, 10 April 1850; Colonist, 11 June 1858; Wellington Independent (WI), 12 May 1870; Star (Christchurch), 11 November 1881.

46 Nelson Examiner and Chronicle, 17 July 1866; Inangahua Times, 2 May 1884; Malthus, 'Dressmakers', p.83.

47 I am indebted for this insight into workroom culture to Pamela Wood for her recollections of her mother's work history.

48 Gordon Parry in Malthus, 'Dressmakers', p.85; Mataura Ensign, 21 March 1899.

49 Stone's Otago \& Southland Directory, 1887-1939. Malthus notes that by 1890 there were 35 drapers' shops in the Dunedin region, many offering ready-to-wear clothing. Malthus, working paper, p.8.

50 Malthus notes: 'Fashionable dresses of the 1870s and 1880s did not lend themselves to factory methods of production, being heavily draped and trimmed, and requiring a close fit to look their best. It was not until the advent of . . . the simpler styles of the 1890s that dressmaking workrooms were able to adopt some industrial techniques'. Malthus, 'Dressmakers', pp.91-2.

51 S.R.H. Jones, Doing Well \& Doing Good: Ross \& Glendining. Scottish Enterprise in New Zealand, Dunedin, 2010, p.200.

52 Jones, p.202.

53 Gamber, p.74.

54 Candler, cit. Russell, p.66.

55 Hawkes' Bay Herald, 11 April 1879.

56 EP, 14 February 1893. See also police reports in Auckland Star (AS), 23 July 1872 and 11 September 1899. Several court cases also called dressmaker-neighbours of suspected brothels to give evidence indicating the proximity of dressmakers and prostitutes in the city.

57 AS, 23 July 1872, p.2. See also AS, 11 September 1899, p.5

58 'Sewing is very dear, they charge from 14/- to a £1 for making a good dress; when I say good dress I mean well made', Sarah Liggins to her sister-in-law, Ellen Liggins, 18 November 1885, www.hyper.net.nz/Liggings.Family.Tree. 


\section{Hunting, Fashion and Colonial Culture}

59 WI, 22 August 1863.

60 See for another example William Sly in EP, 7 May 1898; EP, 2 April 1925.

61 Otago Daily Times, 19 March 1887.

62 See, for example, bankruptcy notice in Taranaki Herald, 17 February 1894.

63 Mrs Haweis, cit. Asa Briggs, Victorian Things, London, 1988, p.261.

64 Magarete Braun-Ronsdorf, The Wheel of Fashion: Costume Since the French Revolution 1789-1929, London, 1964, p.171; on hatpins see Briggs.

65 Braun-Ronsdorf, p.176.

66 Ibid., p.174.

67 Otago Witness, 29 June 1872, p.5.

68 Star, 4 June 1883.

69 New Zealand Tablet, 5 July 1906, p.15; Wanganui Chronicle, 12 Oct 1899, p.2; Feilding Star, 2 July 1902, p.2.

70 Wanganui Herald, 27 June 1899, p.2.

71 Mary Stuart Seddon Hay, Scrapbook, MSy2028, Alexander Turnbull Library, Wellington

72 Suzanne McWha, "Momentous for time and eternity": The Photographic Portrait of Miss Marion Henty', PhD thesis, La Trobe University, 2009.

73 New Zealand Graphic, 23 Jan 1897 in Hay Scrapbook.

74 Photograph in New Zealand Graphic, 23 Jan 1897 in Hay Scrapbook.

75 Russell, especially chapter 2.

76 Colonist, 22 Feb 1902, p.3.

77 Kirk, cit. Star, pp.143-5.

78 For a summary of these debates and various pieces of legislation see Star and Hunter. 
Journal of New Zealand Studies 